\title{
PENGARUH INTERAKSI DALAM KELUARGA DAN PERCAYA DIRI ANAK TERHADAP KEMANDIRIAN ANAK
}

\author{
Sahrip \\ Prodi Pendidikan Anak Usia Dini, PPs Universitas Negeri Jakarta \\ email: sahriparip@gmail.com
}

\begin{abstract}
Abstrak
Tujuan dari penelitian ini adalah untuk mencari besarnya pengaruh interaksi dalam keluarga dan percaya diri anak terhadap kemandirian anak usia 5-6 tahun di kecamatan praya timur kabupaten Lombok tengah. Penelitian ini dilakukan selama 7 bulan mulai dari persiapan hingga sampai akhir. Teknik random sampling diterapkan, dan mengambil 68 siswa sebagai sampel penelitian. Berdasarkan hasil penelitian secara umum dapat disimpulkan, 1) tidak ada pengaruh langsung antara interaksi dalam keluarga dengan kemandirian anak, 2) terdapat pengaruh langsung positif antara percaya diri dengan kemandirian anak, artinya semakin baik percaya diri anak maka akan semakin memperdalam kemandirian anak, 3) terdapat pengaruh langsung positif interaksi dalam keluarga terhadap percaya diri anak, semakin baik interaksi yang dibangun oleh orang tua maka semakin baik pula kepercayaan diri anak.
\end{abstract}

\section{Kata kunci: Interaksi dalam keluarg;, kemandirian; percaya diri}

\section{Abstract}

This research aims to find out how big the influence of interaction in family and confidence of the independence grade 5-6 year free school in the east praya of central Lombok. The research used a quantitative approach, with path analysis technique. This research was conducted for 7 months from the preparation phase to preparation of the final result. The multistage cluster random sampling technique is applied, which 68 students involved as the research sample. Base on the result of this research are generated that: 1) there is no direct positive influence between the Interaction with family with the child's independence. 2) there is a direct positive influence between self confidence and the independence of children, this means that the better the children's confidence then have an impact on the development of children's independence, 3) there is a direct positive influence of interaction in family with self confidence that is the better the interaction between children and parent resulted in the development of self confidence is good too.

Keywords : Interaction in family; self- independence; confidence, 


\section{PENDAHULUAN}

Pendidikan merupakan sebuah investasi yang dapat diwariskan kepada generasai yang akan datang karena terdapat suatu proses pertumbuhan dan perkembangan yang berlangsung sepanjang hayat. Pendidikan pada dasarnya dilakukan untuk mempersiapkan peserta didik dalam menghadapi kehidupan dan dapat diterima dengan baik dalam masyarakat. Karena untuk mewujudkan manusia yang berkualitas menjadi tanggung jawab kita yakni pemerintah, masyarakat, dan lembaga pendidikan.

Pribadi yang mandiri adalah kemampuan hidup yang utama dan salah satu kebutuhan setiap manusia di awal usianya. Anak meskipun usianya masih sangat muda namun diharuskan memiliki pribadi yang mandiri. Alasan mengapa hal ini diperlukan karena ketika anak terjun ke lingkungan di luar rumah sudah tidak tergantung kepada orang tua. Misalnya ketika anak sudah mulai bersekolah, orang tua tidak mungkin selalu menemani mereka tiap detiknya. Mereka harus belajar mandiri dalam mencari teman, bermain, dan belajar. Namun kondisi ini tidak selalu harus instan, ibu misalnya ketika mengantar anaknya kesekolah tidak perlu langsung meninggalkan anak begitu saja dengan guru atau dengan teman-temannya yang lain.ibu dapat melihat anaknya dari jendela kelas sehingga anak merasa nyaman bahwa ibunya sedang mengawasi dan berada dekat dengannya. Setelah terbiasa ibunya dapat sedikit-sedikit meninggalkan anaknya kemudian menjadi kebiasaan dan anak pun tumbuh menjadi pribadi yang mandiri.

Membicarakan tentang kemandirian anak taman kanak-kanak dimulai dengan melihat definisi taman kanak-kanak. Taman kanak-kanak (kindergarten) menurut 
feeney, Christense dan moravik dalam yamin dan sabri sanan pertama kali dikemukakan oleh Frobel, yaitu dengan kata kinder (child) yang berarti anak dan garten (garden) yang berarti kebun uang secara keseluruhan kebun untuk anak-anak yang dikhususkan bagi anak-anak usia lima tahun.

Chaplin dalam desmita (2011) otonomi adalah kebebasan individu manusia untuk memilih, untuk menjadi kesatuan yang bisa memerintah, menguasai dan menentukan dirinya sendiri. Sedangkan seifert dan hoffnung (1994) mendifinisikan otonomi atau kemandirian sebagai “ the ability to govern and regulate one's own thoughts, feelings, and actions frely and responsibly while overcoming feelings of shame and doubt.

Keluarga merupakan tempat pendidikan bagi anak karena sangat akan berpengaruh pada pembentukan watak dan pribadi mereka. Dari situ potensi anak akan terbentuk apakah baik atau buruk. Potensi anak bergantung pada lingkungan yang menjadi gurunya, karena lingkungan merupakan factor kedua setelah orang tua dalam membentuk kepribadian anak, termasuk kepercayaan diri anak. Percaya diri anak adalah bagain terpenting dalam proses pembelajaran, ini berkaitan dengan sikap dan pola pikir anak dalam kegiatan belajar didalam kelas. Rasa percaya diri merupakan kebutuhan bagi setiap individu, jika anak sudah memiliki rasa percaya diri, maka mereka telah siap menghadapi dinamika yang penuh dengan tantangan. Sikap yakin dengan kemampuan diri sendiri dan tidak menutupi kelemahan-kelemahan diri, dapat mengantarkan anak menjadi sosok dewasa yang mandiri. Adapun kemandirian merupakan kesiapan dari seorang anak dalam suatu kegiatan atau pembiasaan tanpa bantuan dari orang lain. Kemandirian juga dapat dilihat dari tingkah laku anak yang bertanggung jawab, disiplin, rasa percaya diri, mengendalikan emosi, mampu memecahkan masalahnya sendiri untuk melakukan segala suatu yang diinginkannya dengan cara sendiri. 
Seperti yang dikatakan oleh Diane E. papalia yang berkaitan dengan kepercayaan diri anak. Elemen kritis dalam membangun rasa percaya diri anak adalah pengasuhan yang sensitive, responsif, dan konsisten. .Apa bila ketidakpercayaan diri yang mendominasi, maka anak akan memandang dunia sebagai sesuatu yang tidak bersahabat dan tidak dapat diprediksi dan akan memiliki kesulitan dalam memulai hubungan.dan orang tua sehat. Hubungan demikian akan menghasilkan anak yang bahagia, ramah tamah dan di anggap menarik oleh orang lain, relative bebas dari kecemasan, dan sebagai anggota kelompok mereka pandai bekerja sama. Sebaliknya anak yang berpenyesuaian buruk biasanya merupakan produk hubungan orang tua -anak yang tidak baik. Kemandirian atau otonomi adalah kemampuan untuk mengendalikan dan mengatur pikiran, perasaan dan tindakan sendiri secara bebas serta berusaha sendiri untuk mengatasi perasaan-perasaan malu dan ragu-ragu. Dengan otonomi tersebut anak didik diharapkan akan lebih bertanggung jawab terhadap diri sendiri.

\section{Kemandirian Anak}

Kemandirian anak sangat diperlukan karena akan membantu anak sampai dewasa dalam kehidupannya bermasyarakat. Kemandirian sangatlah penting dalam kehidupan seseorang karena merupakan suatu proses pembentukan karakter yang positif. Meningkat kan kemandirian di mulai dari usia dini, yang dimulai pertama dari lingkungan keluarga sebagai tempat pendidikan pertama dalam pra- sekolah. Kemandirian perlu ditingkatkan dan di kembangkan pada tiap tahap perkembangan anak dan pada tiap jenjang pendidikan, yang di mulai dari pendidikan pra-sekolah sampai dengan perguruan tinggi.

Pengertian lain dari Hiram E. Fitzgerald dan John Paul Mckinney menyebutkan kemandirian seseorang anak ditunjukkan ketika anak melakukan aktifitas dan mengatasi kesulitan atau masalah tanpa meminta bantuan. Menyelesaikan persoalan pada definisi 
di atas dapat di contohkan dengan melakukan kegiatan atau tugas sehari-hari tanpa sendiri atau dengan sedikit bimbingan, sesuai dengan tahap perkembangan dan kapasitasnya. Secara singkat dapat disimpulkan bahwa kemandirian mengandung pengertian : Pertama, suatu kondisi di mana seseorang memiliki hasrat bersaing untuk maju demi kebaikan dirinya sendiri. Kedua, mampu mengambil keputusan dan inisiatif untuk mengatasi masalah yang dihadapi. Ketiga, memiliki kepercayaan diri dan melaksanakan tugas tugasnya. Keempat, bertanggung jawab atas apa yang dilakukannya. Perkembangan Kemandirian mencangkup pada beberapa aspek perkembangan anak.

Menurut semiawan (2007) salah satu ciri esensial dari kemandirian adalah secara moral bertanggung jawab atas keputusan-keputusan dalam perkara yang bersifat rasional ataupun emosional. Bentuk-bentuk kemandirian menurut havighusrt dalam desmita (2011) membedakan kemandirian atas 4 bentuk kemandirian yaitu; (1) Kemandirian emosi, yaitu kemampuan mengontrol emosi sendiri dan tidak tergantungnya kebutuhan emosi pada orang lain; (2) Kemandirian ekonomi, yaitu kemampuan mengatur ekonomi sendiri, yaitu kemampuan mengatur ekonomi sendiri dan tidak tergantungnya kebutuhan ekonomi pada orang lain; (3) Kemandirian intelektual, yaitu kemampuan untuk mengatasi berbagai masalah yang dihadapi; (4) Kemandirian sosial, yaitu kemampuan untuk mengadakan interaksi dengan orang lain dan tidak tergantung pada aksi orang lain.

Namun demikian, orang tua sering kali menjadi cemas di titik ini, dan hasilnya adalah anak-anak belajar bahwa terlalu berbahaya jika terlalu ingin tahu tentang dunia William crain (1959,). Dijelaskan juga dalam buku konsep pengembangan kurikulum pendidikan anak usia dini, Sujiono (2012) bahwa kemandirian merupakan upaya yang dimaksudkan untuk melatih anak dalam memecahkan masalahnya. Oleh sebab itu, pembelajaran hendaknya dirancang untuk mengembangkan kemandirian anak, misalnya 
tata cara makan, menggosok gigi, memakai baju, melepas dan memakai sepatu, buang air besar, merapikan mainan setelah digunakan, dan lain-lain.

Selanjutnya Brewer juga menyatakan bahwa kemandirian anak taman kanakkanak indikatornya adalah pembiasaan yang terdiri dari kemampuan fisik, percaya diri, bertanggung jawab, disiplin, pandai bergaul, mau berbagi, mengendalikan emosi Brewer (2007). Dengan demikian dapat di nyatakan bahwa kemandirian anak taman kanakkanak adalah suatu pembiasaan prilaku yang tercakup dalam kemampuan fisik, percaya diri, bertanggung jawab, disiplin, pandai bergaul, mau berbagi dan mampu mengendalikan emosi.

\section{Interaksi Dalam Keluarga}

Interaksi dalam keluarga merupakan bagian dari keharmonisan didalam keluarga, tentu semua keluarga menginginkan terjadinya interaksi yang baik didalam keluarga. Menurut pendapat E. Mavis Hetherington and Ross D Parke " The interaction and emotion relationship between the infant and parents will shape the childrens expextancies and response in subsequent social relationship". Artinya bahwa interaksi dan hubungan emosional antara anak dengan orang tua akan membentuk harapan dan respon anak dalam hubungan sosial berikutnya. Dalam keluarga terjadi hubungan keluarga yang penuh dengan kemesraan antar anggotanya. Rasa kasih sayang orang tua terhadap anak-anaknya merupakan rasa kasih sayang yang murni dan sejati yang timbul secara sepontan dan tidak dibuat-buat dari hati yang tulus dan ikhlas. Apa bila anak didalam keluarga menerima kasih sayang yang cukup dari orang tua maka anak tidak akan mencari kasih sayang diluar rumah.

Pendapat lain dari Newcomb juga mengatakan “ Interaction to refer to any set of observable behaviors on the part of twoor more individuals when there is reason to 
assume that in some part of those persons are responding to each other" maksudnya adalah interaksi berkenaan dengan setiap kumpulan tingkah laku yang dapat diamatiyang terjadi antara dua orang atau lebih dari dua individu, bila ada alsan untuk menganggap bahwa antara orang-orang tersebut sedikit banyak terjadi saling memberikan respon Newcomb (198).

Harlod Bethel juga berpendapat dalam santosa (1999) mengatakan, hilangnya interaksi dalam kehidupan keluarga merupakan suatu pertanda hilangnya hakekat manusia sebagai makhluk sosial, karena setiap anggota keluarga dalam kehidupan sehari-hari harus berkomunikasi satu dengan yang lainnya sebagai upaya mempertahankan keharmonisan keluarga jurnal Volume II. (2013)

\section{Percaya Diri}

Percaya diri anak adalah bagain terpenting dalam proses pembelajaran, ini berkaitan dengan sikap dan pola pikir anak dalam kegiatan belajar didalam kelas. Rasa percaya diri merupakan kebutuhan bagi setiap individu, jika anak sudah memiliki rasa percaya diri, maka mereka telah siap menghadapi dinamika yang penuh dengan tantangan. Sikap yakin dengan kemampuan diri sendiri dan tidak menutupi kelemahankelemahan diri, dapat mengantarkan anak menjadi sosok dewasa yang mandiri. Adapun kemandirian merupakan kesiapan dari seorang anak dalam suatu kegiatan atau pembiasaan tanpa bantuan dari orang lain. Kemandirian juga dapat dilihat dari tingkah laku anak yang bertanggung jawab, disiplin, rasa percaya diri, mengendalikan emosi, mampu memecahkan masalahnya sendiri untuk melakukan segala suatu yang diinginkannya dengan cara sendiri.

Apa bila ketidakpercayaan diri yang mendominasi, maka anak akan memandang dunia sebagai sesuatu yang tidak bersahabat dan tidak dapat diprediksi dan akan memiliki kesulitan dalam memulai hubungan.dan orang tua sehat. Hubungan demikian 
akan menghasilkan anak yang bahagia, ramah tamah dan di anggap menarik oleh orang lain, relative bebas dari kecemasan, dan sebagai anggota kelompok mereka pandai bekerja sama. Sebaliknya anak yang berpenyesuaian buruk biasanya merupakan produk hubungan orang tua -anak yang tidak baik. Kemandirian atau otonomi adalah kemampuan untuk mengendalikan dan mengatur pikiran, perasaan dan tindakan sendiri secara bebas serta berusaha sendiri untuk mengatasi perasaan-perasaan malu dan raguragu. Dengan otonomi tersebut anak didik diharapkan akan lebih bertanggung jawab terhadap diri sendiri.

Lauster (1990) mendifinisikan kepercayaan diri sebagai suatu sikap atau perasaan yakin akan kemampuan diri sendiri, sehingga seseorang tidak mudah terpengaruh oleh orang lain. Davis juga mengatakan Rasa percaya diri merupakan keyakinan pada kemapuan-kemampuan yang dimiliki, keyakinan pada suatu maksud atau tujuan dalam kehidupan dan percaya bahwa dengan akal budi mampu untuk melaksanakan apa yang diinginkan, direncanakan dan diharapkan, Davies 2004: 192.

Lebih lanjut brennecke \& Amich (2002) menyatakan bahwa kepercayaan diri ( self confidence) adalah suatu perasaan atau sikap tidak perlu membandingkan diri dengan orang lain, karena telah merasa cukup aman dan tahu apa yang dibutuhkan di dalam hidup ini. Pendapat lain dari erikson yang di kutip oleh requena dalam yamin dan sabri sanan berpendapat bahwa tugas seorang anak selama tahun pertama kehidupannya adalah mengembangkan rasa percaya diri, Yamin \& Sabri Sanan (2008)

\section{METODE}

Metode yang digunakan dalam penelitian ini adalah metode survey dengan menggunakan pendekatan kuantitatif dan menjelaskan hubungan kausal dengan analisis jalur (path analysis) penelitian dilakukan pada TK di kecamatan praya timur kabupaten 
Lombok tengah NTB. Untuk menarik sampel penelitian ini menggunakan teknik multistage random sampling, jumlah sampel yang di ambil dri 4 sekolah yaitu 68 sampel.

\section{HASIL DAN PEMBAHASAN}

Hasil data yang diproleh dari penelitian ini mengungkapkan bahwa, interaksi dalam keluarga, percaya diri dan kemandirian akan dijelaskan lebih mendetail dengan urutan: 1. Pengaruh interaksi dalam keluarga terhadap kemandirian, 2. Pengaruh percaya diri terhadap kemandirian, 3. Pengaruh interaksi dalam keluarga terhadap percaya diri anak.

\section{Pengaruh Interaksi Dalam Keluarga (X1) Terhadap Kemandirian Anak (X3)}

Dari perhitungan analisis jalur, pengaruh interaksi dalam keluarga terhadap kemandirian, nilai koefisien jalurnya sebesar 0,114 dan nilai koefisien $\mathrm{t}$ hitung sebesar 1,286. Nilai dari koefisien $t_{\text {tabel }}$ untuk $\alpha=0,05$ sebesar 2,000. Oleh karena nilai koefisien

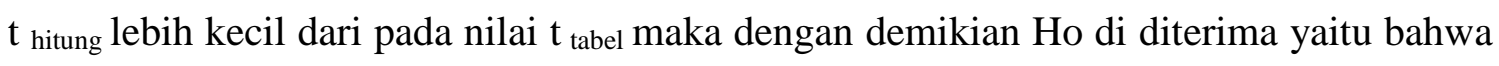
tidak terdapat pengaruh langsung secara signifikan antara interaksi dalam keluarga terhadap kemandirian. Sehingga hipotesis yang menyatakan bahwa interaksi dalam keluarga berpengaruh langsung positif terhadap kemandirian ditolak atau tidak dapat diterima.

Hasil analisis pertama memberikan temuan bahwa interaksi dalam keluarga tidak berpengaruh langsung secara signifikan terhadap kemandirian.

Perhatian yang berlebihan atau pengausahan yang berlebihan justru membuat anak akan merasa nyaman dengan dunia yang dibuat oleh orang tuanya, akibatnya anak sulit menjadi mandiri karena komunikasi atau interaksi yang di bangun berlebihan. Cara 
itu yang membuat anak akan menjadi sosok yang manja dan lambat laun kehidupan seperti itu akan dibawa sampai kehidupan selanjutnya. Orang tua tidak sadar kalau anak itu akan pisah pada waktu besar nanti, pendidikan semacam ini sering menjebak kita selaku orang tua karena dari masa kecil tidak mempercayai anak untuk bisa melakukan sesuatu dengan sendiri.

Kebutuhan hidup anggota keluarga tentu sangat diperlukan adanya interaksi yang baik dan intensif di antara individu-individu dalam keluarga. Begitu juga sebaliknya orang tua selalu berinteraksi dan mengkomunikasikan pesan-pesan kepada anak maupun anggota keluarga lainnya yang bersifat mendidik, sebagai upaya mempertahankan nilainilai keharmonisan dalam kehidupan keluarga dan bermasyarakat. interaksi yang berlebihan antara orang tua dan anak akan mempunyai efek negatif, ketika orang tua tidak ada di rumah atau di sekolah anak merasa tidak aman dan merasa takut. Karena itu orang tua semestinya sadar bahwa sikap orang tua yang terlampau melindungi atau mengarahkan perilaku anak membuat anak merasa ragu untuk berinisiatif. Jika orang tua selalu membiasakan berinteraksi dengan semua kondisi anak atau menolong semua aktifitas anak di rumah seperti, makan, mandi, minum susu semua melibatkan orang tua bahkan orang tua yang lebih aktif terhadap apa yang menjadi aktifitas anak maka itu wajar bila akhirnya anak sangat tergantung pada orang tua dan kurang bisa mandiri.

Seperti yang diungkapkan oleh Awisol menyatakan bahwa pemanjaan yang berlebihan dan pengabaian orang tua terhadap anak mengakibatkan terhambatnya kemandirian anak. Pendapat lain juga mengatakan pengasuhan orangtua juga turut membentuk kemandirian seseorang. Toleransi yang berlebihan, pemeliharaan berlebihan dan orang tua yang terlalu keras kepada anak menghambat pencapaian kemandirian (prasetyo dan sutoyo). 
Beberapa penelitian juga menunjukkan bahwa anak yang mengalami gangguan kelekatan memiliki orang tua yang mengalami masalah yang sama dimasa kecilnya. Cicchetty \& Cohen (1995) Pengasuhan yang tidak menyenangkan akan membuat anak tidak mandiri dan mengembangkan kelekatan tidak aman (insecure attachment). Kelekatan yang tidak aman dapat membuat anak mengalami berbagai permasalahan yang disebut dengan gangguan kelekatan (attachment disorder). Telah disebutkan di atas bahwa gangguan kelekatan terjadi karena anak gagal membentuk kelekatan yang aman dengan figure lekatnya. Selanjutnya ketidakpercayaan orang tua atau tidak beraninya orang tua untuk memberikan ruang kepada anak mulai dari hal terkecil, membereskan mainan, mandi sendiri, atau bermain sama teman-temannya merupakan cara yang keliru dilakukan sehingga anak terbiasa tidak mandiri mulai dari sejak kecil. Hanya saja kita kadang berlebihan dalam mencintai anak sehingga efeknya sangat besar, lambat laun kita lah yang menjadi penghambat kemandirian anak tersebut. Orang tua harus lebih peka terhadap masa depan anak dalam artian dari kecil semestinya kita memberikan ruang atau mendukung anak untuk tumbuh menjadi anak yang mandiri dengan cara memberikan ruang kepada anak untuk bisa melakukan sesuatu dengan sendiri ketika mereka masih kecil.

Dari pendapat diatas akan menjadi pegangan peneliti untuk mengungkap fakta dilapangan atau hasil dari penelitian ini. Perhatian yang berlebihan atau pengausahan yang berlebihan justru membuat anak akan merasa nyaman dengan dunia yang dibuat oleh orang tuanya, akibatnya anak sulit menjadi mandiri karena komunikasi atau interaksi yang di bangun berlebihan. Sehingga itu yang membuat anak akan menjadi sosok yang manja dan lambat laun kehidupan seperti itu akan dibawa sampai kehidupan selanjutnya. Orang tua tidak sadar kalau anak itu akan pisah pada waktu besar nanti, pendidikan semacam ini sering menjebak kita selaku orang tua karena dari masa kecil tidak mempercayai anak untuk bisa melakukan sesuatu dengan sendiri. 


\section{Pengaruh Percaya Diri $\left(\mathbf{X}_{2}\right)$ Terhadap Kemandirian $\left(\mathbf{X}_{3}\right)$.}

Dari perhitungan analisis jalur, pengaruh percaya diri terhadap kemandirian, nilai koefisien jalurnya sebesar 0,676 koefisien $t$ hitung sebesar 7,586. Nilai dari koefisien $t$ tabel untuk $\alpha=0,05$ sebesar 2,000. Oleh karena nilai koefisien $t$ hitung lebih besar dari pada nilai $\mathrm{t}$ tabel maka dengan demikian Ho di tolak dan Hi diterima yaitu bahwa percaya diri berpengaruh langsung secara singnifikan terhadap kemandirian. Sehingga hipotesis yang menyatakan bahwa percaya diri berpengaruh langsung positif terhadap kemandirian dapat diterima.

Hasil analisis pertama memberikan temuan bahwa percaya diri berpengaruh langsung positif secara singnifikan terhadap kemandirian. Dengan demikian dapat disimpulkan bahwa kemandirian dipengaruhi secara langsung positif oleh percaya diri. Meningkatnya percaya diri mengakibatkan peningkatan kemandirian anak.

\section{Pengaruh Interaksi Dalam Keluarga $\left(\mathbf{X}_{1}\right)$ Terhadap Percaya Diri Anak $\left(\mathbf{X}_{2}\right)$}

Dari perhitungan analisis jalur, pengaruh interaksi dalam keluarga terhadap percaya diri, nilai koefisien jalurnya sebesar 0,251 koefisien $t$ hitung sebesar 2,107. Nilai dari koefisien $t_{\text {tabel }}$ untuk $\alpha=0,05$ sebesar 2,000. Oleh karena nilai koefisien $t_{\text {hitung lebih }}$ besar dari pada nilai t tabel maka dengan demikian Ho di tolak dan Hi diterima yaitu bahwa interaksi dalam keluarga berpengaruh langsung secara signifikan terhadap percaya diri. Sehingga hipotesis yang menyatakan bahwa interaksi dalam keluarga berpengaruh langsung positif terhadap percaya diri dapat diterima.

Hasil analisis pertama memberikan temuan bahwa interaksi dalam keluarga berpengaruh langsung positif secara sigifikan terhadap percaya diri. Dengan demikian dapat disimpulkan bahwa percaya diri dipengaruhi secara langsung positif oleh interaksi 
dalam keluarga. Meningkatnya interaksi dalam keluarga mengakibatkan peningkatan pada percaya diri anak.

\section{KESIMPULAN}

Penelitian ini dilakukan pada TK dikecamatan praya timur kabupaten Lombok tengah NTB. Sesuai dengan tujuan permasalahan yang telah dirumuskan . interaksi dalam keluarga tidak berpengaruh terhadap kemandirian anak (tidak significan). Selanjutnya percaya diri anak berpengaruh langsung positif terhadap kemandirian anak. Dan interaksi dalam keluarga berpengaruh langsung positif terhadap percaya diri anak.

Interaksi dalam keluarga terhadap kemandirian tidak berpengaruh positif atau tidak teruji artinya memberikan perhatian yang berlebihan kepada anak atau dimanjakan tidak memberikan kemandirian kepada anak. Selanjutnya interaksi dalam keluarga terhadap percaya diri berpengaruh langsung positif ini artinya memberikan kita gambaran bahwa interaksi yang dibangun oleh orang tua terhadap anak akan berpengaruh besar tyerhadap percaya diri anak. Tentu ini sangat bermanfaat bagi orang tua untuk terus memberikan motifasi agar percaya diri anak semakin tumbuh. Dan yang terakhir percaya diri anak terhadap kemandirian anak, ini berpengaruh besar karena ketika anak sudah terbangun percaya dirinya maka anak tersebut secara otomatis akan mampu mandiri. Semakin percaya diri anak meningkat maka kemandirian anak tersebut juga semakin meningkat.

Terdapat pengaruh langsung antara percaya diri terhadap kemandirian. Artinya adalah jika percaya diri anak sudah terbangun maka itu menjadi penopang anak untuk bisa mulai mandiri dari hal-hal yang kecil. Ini penting untuk dimiliki oleh anak sehingga kemandirian dari usia dini akan menjadi modal yang besar untuk kehidupan anak di TK kecamatan praya timur kabupaten Lombok tengah. 
Terdapat pengaruh langsung antara interaksi dalam keluarga terhadap percaya diri anak. Artinya adalah meningkatnya komunikasi antara orang tua dan anak atau dengan intensif dilakukan oleh orang tua terhadap anak maka anak lahir menjadi anak yang percaya diri yang dilakukan oleh orang tua anak di TK kecamatan praya timur kabupaten Lombok tengah

\section{REKOMENDASI}

Berdasarkan kesimpulan yang sudah kami paparkan diatas, adapun rekomendasi yang dapat diambil untuk bagi kepala sekolah dan guru Tk adalah sebagai berikut.

1. Bagi guru, dan pendidik Taman Kanak-kanak, bahwa kemandirian anak sangat penting untuk diajarkan kepada anak didik kita. Karena kemandirian akan berdampak besar untuk kehidupan selanjutnya nanti. Untuk itu mari memberikan ruang kepada anak didik kita untuk terus memberikan ruang agar mereka mampu menciptakan kemandirian dengan dasar kepekaan kita selaku guru.

2. Untuk orang tua, semoga hasil penelitian ini dapat diambil sebagai bahan masukan untuk kita agar bisa mewujudkan interaksi yang baik terhadap anak-anak kita dan keluarga. Karena dampaknya sangat besar bagi kehidupan anak maka intensitas interaksi terus dikembangkan, agar anak bisa lebih percaya diri dan mandiri.

3. Untuk pemerintah, harus bersinergui dengan pihak sekolah dan orang tua siswa untuk sama-sama memberikan ruang yang positif kepada peserta didik agar kedepan mampu menghasilkan sumberdaya manusia yang bisa diharapkan. Peran pemerintah tidak diragukan lagi terhadap kemajuan pendidikan kita, maka sudah seharusnya saling bahu membahu antara pemerintah dan guru serta para orang tua untuk bisa menghasilkan pendidikan yang lebih baik kedepannya.

\section{DAFTAR PUSTAKA}


E Diane, Papalia. (2010). Human Development. Edisi ke Sembilan. Jakarta : Kencana Prenada Group.

Fitzgerald and John, Paul Mckinney, and Hiram E. (1970). Developmental Psychology. USA: The Dorsey Press.

Neneng Tasu'ah. (2013). Pengaruh Kegiatan Extra Feeding Dan Pola Asuh Orang Tua Terhadap Kemandirian Anak. Jurnal Pendidikan Anak Usia Dini. Pascasarjana Universitas Negeri Jakarta.

Crain, William. (2007). Teori Perkembangan Konsep dan Aplikasi. Yogyakarta: Pusataka Pelajar Edisi Ke Tiga.

Cicchetty \& Cohen, (1995). Developmental Psycopatology Volume 2. Risk Diaorder and Adaptation (Jhon and Sons Inc).

Sujiono. (2012). Konsep Dasar Pendidikan Anak Usia Dini. Jakarta: PT Indeks.

Yamin, dan Sabri Sanan. (2010). Panduan Pendidikan Anak Usia Dini. Jakarta: Gaung Persada.

Newcomb, Theodore \& Converse, Philip. (1985). Social Psichology. New York: Sage Publication.

Yigibalaom. (2013). Peranan Interaksi Anggota Keluarga Dalam Upaya Mempertahankan Harmonisasi Kehidupan Keluarga di Desa Kumuluk Kecamatan Tiom Kabupaten Lanny Jaya. Jurnal Volume II. No. 4.

Davies, P. (2004). Meningkatkan Rasa Percaya Diri .Alih Bahasa Saut Pasaribu. (Yogyakarta, torent books), h., 192.

Idrus, dan Rohmiati. (2014). Hubungan Kepercayaan Diri Remaja Dengan Pola Asuh Orang Tua Etnis Jawa. Sumber: https://www.google.com/search?q=jurnal+hubungan+kepercayaan+diri+remaja+ $\underline{\text { dengan+pola+asuh+etnis }+ \text { jawa } \& i e=u t f-8 \& o e=u}$. 